\title{
Solid Phase Microextraction (SPME) Analysis of Volatile Compounds Produced by In Vitro Shoots of Lantana camara L. under the Influence of Auxins and Cytokinins
}

\author{
Vanessa Ribeiro Affonso, ${ }^{a}$ Humberto Ribeiro Bizzo, ${ }^{b}$ Sharon Santos de Lima, ${ }^{a}$ \\ Maria Apparecida Esquibel ${ }^{a}$ and Alice Sato ${ }^{*, c}$ \\ ${ }^{a}$ Instituto de Biofisica Carlos Chagas Filho, Universidade Federal do Rio de Janeiro, CCS, \\ Bloco G, Cidade Universitária, Ilha do Fundão, 21952-590 Rio de Janeiro-RJ, Brazil \\ ${ }^{b}$ EMBRAPA Agroindústria de Alimentos, Avenida das Américas 29501 \\ 23020-470 Rio de Janeiro-RJ, Brazil \\ ${ }^{c}$ Departamento de Botânica, Universidade Federal do Estado do Rio de Janeiro, CCBS, \\ Avenida Pasteur 458, 22290-040 Rio de Janeiro-RJ, Brazil
}

\begin{abstract}
Neste trabalho foram avaliados os efeitos da auxina ácido indol acético $\left(0,44 \mu \mathrm{mol} \mathrm{L}^{-1}\right)$ e das citocininas thidiazuron $\left(0,44 \mu \mathrm{mol} \mathrm{L} \mathrm{L}^{-1}\right)$ e benziladenina $\left(0,44\right.$ e $\left.4,4 \mu \mathrm{mol} \mathrm{L}^{-1}\right)$ sobre o desenvolvimento e produção de compostos voláteis de plantas in vitro de Lantana camara L. Os voláteis foram extraídos por microextração em fase sólida (SPME) e analisados utilizando cromatografia com fase gasosa acoplada à espectrometria de massas (GC-MS). Plantas cultivadas in vitro, nos diferentes tratamentos, apresentaram aumento na produção de mirceno, $\alpha$-felandreno, $\alpha$-copaeno, trans-cariofileno e $\beta$-gurjuneno, e redução de $\alpha$ e $\beta$-pineno, quando comparadas com a planta matriz.

The effects of the auxin indole-3-acetic acid at $0.44 \mu \mathrm{mol} \mathrm{L}^{-1}$ and the cytokinins thidiazuron at $0.44 \mu \mathrm{mol} \mathrm{L}-1$ and benzyladenine at 0.44 and $4.4 \mu \mathrm{mol} \mathrm{L}^{-1}$ on growth, development and volatile compounds production of Lantana camara L. in vitro plants were investigated. The volatiles were extracted by solid phase microextraction (SPME) and the quantification was performed using GC-MS. A higher content of myrcene, $\alpha$-phellandrene, $\alpha$-copaene, trans-caryophyllene and $\beta$-gurjunene, and the lower levels of $\alpha$-pinene and $\beta$-pinene were observed in in vitro plants cultivated on different supplementation media than in donor plants.
\end{abstract}

Keywords: Lantana camara L., volatile compounds, SPME, growth regulators, tissue culture

\section{Introduction}

Lantana camara L. (Verbenaceae), commonly known as wild or red sage, is native of tropical and subtropical America. However, this species is cultivated world-wide as an ornamental plant. ${ }^{1}$

Although some taxa of the widely variable $L$. camara are toxic to ruminants, ${ }^{2}$ the plant has been used in folk medicine, in many parts of the world, to treat fever, influenza, asthma, bronchitis and a variety of other disorders. ${ }^{1}$ In Brazil, the plant is used specially to treat rheumatism and pulmonary problems rough. ${ }^{3}$

Studies on the chemical composition of the essential oils of L. camara leaves and flowers from different origins

*e-mail: alissat@uol.com.br showed a great variation in chemical composition with high percentage of sesquiterpenes. ${ }^{4,5}$ Differences in composition were observed with samples obtained from different places in Brazil. ${ }^{4}$ The essential oil of $L$. camara showed a wide spectrum of antibacterial and antifungal activities. ${ }^{6}$ Besides, the plant also had an insecticidal effect on Sitophilus zeamais (Coleoptera, Curculionidae) suggesting it is possible to use essential oil extracts from L. camara to protect stored grains. ${ }^{7}$

Plant tissue culture can be used to induce quantitative and qualitative modifications on the production of plant secondary metabolites ${ }^{8}$ by changing nutrient medium culture composition with phytohormones addition into the medium. ${ }^{9}$ Investigations on the influence of growth regulators on essential oil composition and yield are numerous and a variety of effects on secondary metabolites 
production profiles when compared with donor plant have been reported. ${ }^{10,11}$

The scope of the present study was to investigate the influence of growth regulators on the production of volatile compounds by in vitro plantlets of Lantana camara L., using solid phase microextraction (SPME) and gas chromatography/mass spectrometry.

\section{Experimental}

\section{Plant material}

Seeds collected from L. camara wild plants were used as source of plant material. A voucher specimen $n^{\circ}$ RFA 31226 was deposited at the herbarium of Biology Institute of Universidade Federal do Rio de Janeiro. The cultures were established according to Affonso. ${ }^{12}$ Nodal segments excised from in vitro culture seedlings were inoculated in basal medium Murashige and Skoog (MS). ${ }^{13}$ MS without growth regulators (MS0) were maintained under white light illumination (Sylvania fluorescent tubs) under $1.6 \mathrm{~W} \mathrm{~m}^{-2}$, $23 \mu \mathrm{mol} \mathrm{m} \mathrm{m}^{-2} \mathrm{~s}^{-1}$ daily photoperiod of $16 \mathrm{~h}$ at $25 \pm 2{ }^{\circ} \mathrm{C}$.

\section{Treatment with growth regulators}

Plantlets were sub cultured in different media: MS0 (control), $\mathrm{MS}+0.44 \mu \mathrm{mol} \mathrm{L}-1$ Indole-3-acetic acid (IAA), MS $+0.44 \mu \mathrm{mol} \mathrm{L}{ }^{-1}$ Benzyladenine (BA), MS $4.4 \mu \mathrm{mol} \mathrm{L}^{-1} \mathrm{BA}$ and MS $+0.44 \mu \mathrm{mol} \mathrm{L}^{-1}$ Thidiazuron (TDZ) for 75 days.

\section{Extraction}

Donor plant and in vitro plantlets were submitted to solid phase microextraction (SPME). The SPME apparatus was purchased from Supelco Inc. A $65 \mu \mathrm{m}$ polydimethylsiloxane divinylbenzene (PDMS/DVB) fiber was used. For each extraction, $0.1 \mathrm{~g}$ of fresh leaves was placed in a $4 \mathrm{~mL}$ vial. In each extraction the sample was kept for $1 \mathrm{~h}$ in repose at ambient temperature to achieve the partition equilibration between the sample and headspace. After this time, the SPME fiber was exposed to the headspace of the sample to adsorb analytes. After 15 minutes, the fiber was withdrawn into the needle and then introduced into a heated chromatographic injector for desorption for 3 minutes.

\section{Gas chromatography and gas chromatography-mass} spectrometry

The analyses were performed in a Perkin-Elmer Autosystem gas chromatograph equipped with HP-5 (5\% phenylmethyl silicone) fused capillary column (20 $\mathrm{m} \times$ $0.18 \mathrm{~mm}$ id, film thickness $=0.40 \mu \mathrm{m}$ ) and a flame ionization detector (FID). The oven temperature was programmed from $40{ }^{\circ} \mathrm{C}$ to $240{ }^{\circ} \mathrm{C}$ at $3{ }^{\circ} \mathrm{C} \mathrm{min}{ }^{-1}$ with an initial isothermal period of $3 \mathrm{~min}$, splitless. The injector temperature was kept at $250{ }^{\circ} \mathrm{C}$ and the detector at $280{ }^{\circ} \mathrm{C}$. Hydrogen was used as carrier gas at a linear velocity of 1 $\mathrm{mL} \min ^{-1}$.

The GC/MS analyses were carried out on an Agilent 5973 mass selective detector coupled to an Agilent 6890 gas chromatograph, equipped with HP-5 (5\% phenylmethyl silicone) fused capillary column $(30 \mathrm{~m} \times$ $0.25 \mathrm{~mm} \mathrm{id}$, film thickess $=0.25 \mu \mathrm{m})$. The mass spectrometer was operated on electron impact mode at 70 $\mathrm{eV}$. The oven temperature was programmed from $60{ }^{\circ} \mathrm{C}$ to $240{ }^{\circ} \mathrm{C}$ at $3{ }^{\circ} \mathrm{C} \mathrm{min}{ }^{-1}$ and injector temperature was the same as above. Injections were made in splitless mode and helium was used as the carrier gas at linear velocity of $1 \mathrm{~mL} \mathrm{~min}^{-1}$.

\section{Identification of the volatiles}

Compounds were identified by comparison of mass spectra with those in a Wiley $6^{\text {th }}$ edition library and by comparison of GC retention indices calculated by linear interpolation to retention times of a series of $n$-alkanes $\left(\mathrm{C}_{7}-\mathrm{C}_{26}\right)$, with those reported in the literature. ${ }^{14}$ Quantification was performed from GC profiles using relative area $(\%)$.

\section{Statistics}

Data obtained were subjected to the analyses of variance (ANOVA) and means were compared by the Tukey's test at $5 \%$ significance.

\section{Results and Discussion}

Development of in vitro L. camara shoots occurred in all different growth regulators supplemented media and the results obtained were compared with those from plantlets cultured on MS0 medium (control).

The number of shoots per explant formed was not significantly different among the different types of media. However, the growth and development of nodal segments varied considerably with the growth regulator treatment (Table 1).

Addition of $4.4 \mu \mathrm{mol} \mathrm{L}{ }^{-1} \mathrm{BA}$ or $0.44 \mu \mathrm{mol} \mathrm{L}^{-1} \mathrm{TDZ}$ to the MS medium resulted in a significant decrease on the length of shoots formed and on root formation, although media supplementation with $4.4 \mu \mathrm{mol} \mathrm{L}^{-1} \mathrm{BA}$ resulted in 
the highest number of shoots per explant and in the highest number of nodes per plantlet. Multiple shoots and nodes formed in shorter plantlets turns the nodal segments individual isolation too difficult what is not desired for micropropagation.

IAA at $0.44 \mu \mathrm{mol} \mathrm{L}^{-1}$ was considered the best hormonal supplementation for multiplication of the culture. However no significant difference was observed in plantlets cultured on this media and in MS0 media (control).

The volatiles obtained from donor plants and from in vitro plantlets by SPME extraction showed quantitative and qualitative variation. Compounds are listed on Table 2.

Plantlets cultivated on MS medium produced less compounds than donor plants as we can see on Table 2 . Besides, plantlets cultivated in vitro, on MS0 medium, produced lower quantities of $\alpha$-pinene and $\beta$-pinene, but produced more myrcene, $\alpha$-phellandrene, $\alpha$-copaene, trans-caryophyllene and $\beta$-gurjunene than donor plants (Figure 1).

Variation on essential oil composition produced in plants related to different developmental stages has already been reported for some species. ${ }^{15}$ Besides, parameters as climatic factors, environment and cultivation site must be also considered.

In vitro plants are exposed to a microenvironment (humidity, light levels, nutrients) selected to provide optimal conditions for plant growth, development and multiplication with minimal stress. On the other hand, field plants are continuously exposed to more stressful conditions, especially due to pathogens and insects predation. It stimulates essential oil production since many secondary metabolites are toxic to these organisms acting as defense substances.

Comparing volatile compounds data from in vitro plantlets cultivated in MS0 medium (control) with those cultivated in MS media supplemented with different types and concentrations of growth regulators it was observed that addition of $0.44 \mu \mathrm{mol} \mathrm{L}{ }^{-1}$ IAA in the medium resulted in an increase in $\alpha$-pinene and $\beta$-pinene levels about $148 \%$ and $94 \%$ respectively, while addition of $0.44 \mu \mathrm{mol}$ $\mathrm{L}^{-1} \mathrm{TDZ}$ resulted in an increase in trans-caryophyllene level about $54 \%$. The kind of proteins formed in a plant cell before or soon as growth promotion starts may be affected by auxins which can changes the level of some substances through the modification of the cell enzymatic pattern. ${ }^{11}$

BA at $0.44 \mu \mathrm{mol} \mathrm{L} \mathrm{L}^{-1}$ added to MS medium increased proportion of myrcene about $80 \%$ and $\alpha$-phellandrene about $15 \%$ while BA at highest concentration $(4.4 \mu \mathrm{mol}$ $\left.\mathrm{L}^{-1}\right)$ caused an increase of $\alpha$-pinene and $\beta$-pinene about $130 \%$ and $75 \%$ respectively, when compared with control plants (MS0).

Table 1. Effect of type and concentration of plant growth regulators after 60 days of culture ( $m e a n \pm s . e, n=30$ by treatment)

\begin{tabular}{|c|c|c|c|c|}
\hline Culture media & Number of shoots per explant & Number of nodes per plantlet & Shoot length & Root frequency / (\%) \\
\hline MS0 & $3.25 \pm 0.42$ & $13.59 \pm 1.14$ & $7.46 \pm 0.43$ & 87.5 \\
\hline $\mathrm{MS}+0.44 \mu \mathrm{mol} \mathrm{L}^{-1} \mathrm{IAA}$ & $3.41 \pm 0.42$ & $12.44 \pm 0.62$ & $8.55 \pm 0.52$ & 93.7 \\
\hline $\mathrm{MS}+0.44 \mu \mathrm{mol} \mathrm{L}^{-1} \mathrm{TDZ}$ & $2.31 \pm 0.31$ & $9.88 \pm 0.61$ & $4.71^{\mathrm{s}} \pm 0.12$ & $18.7^{\mathrm{s}}$ \\
\hline $\mathrm{MS}+0.44 \mu \mathrm{mol} \mathrm{L}^{-1} \mathrm{BA}$ & $2.59 \pm 0.27$ & $10.50 \pm 0.75$ & $6.41 \pm 0.27$ & 75.0 \\
\hline $\mathrm{MS}+4.4 \mu \mathrm{mol} \mathrm{L}-1 \mathrm{BA}$ & $4.61 \pm 0.65$ & $19.46^{\mathrm{s}} \pm 1.67$ & $5.72^{\mathrm{s}} \pm 0.38$ & $42.9^{\mathrm{s}}$ \\
\hline
\end{tabular}

'Indicates significant differences by comparison with control $(\mathrm{p}<0.05)$.

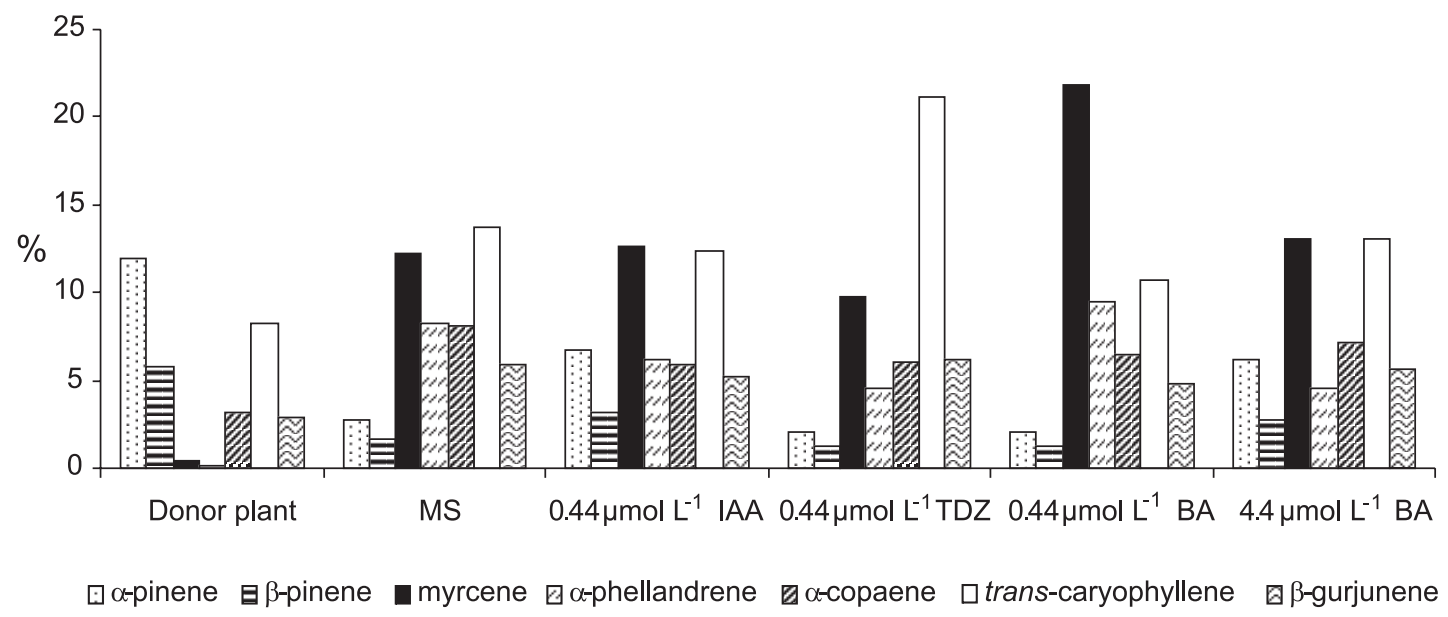

Figure 1. Composition (\%) of the major volatile components of aerial parts from donor plants and from 75 days old in vitro plantlets cultivated in different media. 
Table 2. Composition (\%) of the volatile components of aerial parts from donor plants and from 75 days old in vitro plantlets cultivated in different media

\begin{tabular}{|c|c|c|c|c|c|c|}
\hline \multirow[t]{3}{*}{ Volatile components } & \multicolumn{5}{|c|}{ Relative area / (\%) } & \multirow[b]{3}{*}{$4.4 \mu \mathrm{mol} \mathrm{L}^{-1} \mathrm{BA}$} \\
\hline & \multirow[t]{2}{*}{ Donor plants } & \multicolumn{4}{|c|}{ In vitro plantlets } & \\
\hline & & MS0 & $0.44 \mu \mathrm{mol} \mathrm{L}^{-1} \mathrm{IAA}$ & $0.44 \mu \mathrm{mol} \mathrm{L}{ }^{-1} \mathrm{TDZ}$ & $0.44 \mu \mathrm{mol} \mathrm{L}^{-1} \mathrm{BA}$ & \\
\hline$\alpha$-thujene & 1.1 & - & 0.4 & 0.3 & - & - \\
\hline$\alpha$-pinene & 11.9 & 2.7 & 6.7 & 2.1 & 2.1 & 6.2 \\
\hline camphene & 0.4 & - & - & - & - & - \\
\hline sabinene & 1.5 & - & 0.7 & 0.4 & - & - \\
\hline$\beta$-pinene & 5.8 & 1.6 & 3.1 & 1.3 & 1.3 & 2.8 \\
\hline 3-octanone & 0.2 & - & - & - & - & - \\
\hline myrcene & 0.4 & 12.2 & 12.7 & 9.8 & 21.9 & 13.0 \\
\hline 3-octanol & 0.2 & - & - & - & - & - \\
\hline$\alpha$-phellandrene & 0.2 & 8.3 & 6.2 & 4.6 & 9.5 & 4.5 \\
\hline acetate-3-hexen-1-ol & 0.6 & - & - & - & - & - \\
\hline$\alpha$-terpinene & 1.9 & - & - & - & - & - \\
\hline$p$-cimene & 0.7 & - & - & 0.2 & - & - \\
\hline limonene & 0.5 & - & - & 0.3 & - & - \\
\hline 1,8-cineole & 3.5 & - & - & - & - & - \\
\hline (E)- $\beta$-ocimene & 0.4 & - & - & 0.1 & - & - \\
\hline$\alpha$-terpinolene & 0.2 & - & - & - & - & - \\
\hline$\delta$-elemene & 0.3 & - & - & 0.5 & - & - \\
\hline$\alpha$-cubebene & 0.7 & 1.1 & 0.8 & 1.3 & - & 0.8 \\
\hline cyclosativene & - & 0.6 & - & 0.3 & - & - \\
\hline$\alpha$-ylangene & 0.3 & - & - & 0.7 & - & - \\
\hline$\alpha$-copaene & 3.2 & 8.1 & 5.9 & 6.1 & 6.4 & 7.2 \\
\hline$\beta$-bourbonene & 1.0 & 0.8 & 0.6 & 1.1 & - & - \\
\hline$\beta$-cubebene & 0.5 & 1.8 & 1.4 & 0.6 & 1.3 & 1.5 \\
\hline$\beta$-elemene & 0.7 & - & - & 0.5 & - & - \\
\hline n.i. & 1.4 & 3.5 & 2.9 & 1.7 & 3.3 & 3.0 \\
\hline n.i. & 1.3 & 0.9 & 0.8 & 2.1 & - & 1.4 \\
\hline (Z)-caryophyllene & 0.8 & 4.3 & 3.7 & 1.0 & 4.1 & 3.6 \\
\hline$\alpha$-gurjunene & 1.7 & - & - & 1.4 & - & - \\
\hline n.i. & 0.8 & 1.0 & 1.0 & 0.5 & 1.2 & 1.2 \\
\hline trans-caryophyllene & 8.2 & 13.7 & 12.3 & 21.1 & 10.7 & 13.1 \\
\hline n.i. & 0.7 & 8.0 & 7.0 & 0.7 & 6.7 & 6.5 \\
\hline$\beta$-gurjunene & 2.9 & 5.9 & 5.2 & 6.2 & 4.8 & 5.6 \\
\hline$\gamma$-elemene & 0.9 & 1.0 & 1.1 & 1.1 & - & 1.6 \\
\hline$\alpha$-bergamotene & 1.1 & - & 0.9 & 1.8 & - & - \\
\hline aromadendrene & 1.7 & 2.6 & 2.4 & 1.5 & 3.1 & 3.1 \\
\hline n.i. & - & 0.9 & 0.8 & 0.5 & - & - \\
\hline$\alpha$-himachalene & 0.9 & 0.7 & 0.7 & 1.2 & - & - \\
\hline$\alpha$-humulene & 0.6 & 1.0 & 1.0 & 1.2 & 1.1 & 1.1 \\
\hline$\beta$-farnesene & 1.1 & 2.0 & 1.6 & 0.8 & 2.5 & 2.2 \\
\hline allo-aromadendrene & 1.0 & 1.0 & 0.8 & 1.6 & - & 1.2 \\
\hline muurola-4(14),5-diene & 1.2 & 2.3 & 1.7 & 0.9 & 3.3 & 2.9 \\
\hline n.i. & - & - & - & 0.3 & - & 0.6 \\
\hline n.i. & - & - & - & 0.3 & - & - \\
\hline$\gamma$-gurjunene & 1.0 & 0.7 & 0.4 & 1.4 & 0.6 & - \\
\hline$\gamma$-muurolene & 1.2 & - & 0.2 & 2.3 & - & - \\
\hline germacrene-D & 2.3 & 2.3 & 1.5 & 4.5 & 2.5 & 2.3 \\
\hline$\beta$-selinene & 0.3 & 0.5 & 0.4 & 0.4 & - & - \\
\hline bicyclogermacrene & 2.7 & 1.5 & 1.7 & 4.0 & 1.8 & 3.0 \\
\hline$\alpha$-muurolene & 1.2 & 1.3 & 1.1 & 1.7 & 1.4 & 1.5 \\
\hline$\delta$-guaiene & 0.9 & 0.9 & 0.8 & 1.4 & - & 1.3 \\
\hline$\gamma$-cadinene & 0.6 & 0.3 & 0.4 & 1.2 & 2.3 & - \\
\hline 7-epi- $\alpha$-selinene & 1.0 & 0.7 & 0.5 & 1.0 & - & 1.0 \\
\hline$\delta$-cadinene & 1.9 & 1.9 & 1.7 & 3.4 & - & 2.3 \\
\hline cubebene & - & - & - & 0.3 & - & - \\
\hline$\alpha$-cadinene & 0.2 & - & - & 0.5 & - & - \\
\hline Total (identified) & 71.6 & 89.8 & 78.6 & 92.1 & 80.7 & 82.4 \\
\hline
\end{tabular}




\section{Conclusions}

The results obtained in the present study suggest that the type and concentration of growth regulators can influence Lantana camara L. volatile composition qualitative and quantitatively, although the same major compounds were produced by in vitro plantlets. No direct relation with volatile compounds production and plantlets growth and development was observed. Besides, with our results and literature overview we can conclude that there is no specific relation with type of growth regulators and compound groups specific accumulation.

\section{Acknowledgments}

V. Affonso wishes to acknowledge the Master fellowship from CNPq.

\section{References}

1. Ghisalberti, E. L.; Fitoterapia 2000, 71, 467.

2. Seawright, A. A.; Aust. Vet. J. 1965, 41, 235; Tokarnia, C. H.; Döbereiner, J.; Lazzari, A. A.; Peixoto, P. V.; Pesq. Vet. Bras. 1984, 4, 129; Tokarnia, C. H.; Armién, A. G.; Barros, S. S.; Peixoto, P. V.; Döbereiner, J.; Pesq. Vet. Bras. 1999, 19, 128.

3. Lorenzi, H.; Matos, F. J. A.; Plantas Medicinais no Brasil: Nativas e Exóticas Cultivadas, Instituto Plantarum: Nova Odessa, SP, 2002, p. 487.

4. Da Silva, M. H. L.; Andrade, E. H. A.; Zoghbi, M. G.; Luz, A. I. R.; Da Silva, J. D.; Maia, J. G. S; Flavour Frag. J. 1999, 14, 208.

5. Saleh, M.; Planta Med. 1974, 25, 373; Ngassoum, M. B.; Yonkeu, S.; Jirovetz, L.; Buchbauer, G.; Schmaus, G.; Hammerschmidt, F-J.; Flavour Frag. J. 1999, 14, 245; Khan, M.; Srivastava, S. K.; Syamasundar, K. V.; Singh, M.; Naqvi, A. A.; Flavour Frag. J. 2002, 17, 75; Sefidkon, F.; Flavour Frag. J. 2002, 17, 78; Sundufu, A. J.; Shoushan, H.; Flavour Frag. J. 2004, 19, 229; Pino, J. A.; Marbot, R.; Rosado, A.; Romeu, C.; Marti, M. P.; J. Essent. Oil Res. 2004, 16, 216; Alitonou, G.; Avlessi, F.; Bokossa, E. I.; Ahoussi, E.; Dangou, J.; Sohounhloué, D. C. K.; C. R. Chim. 2004, 7, 1101; Kasali, A. A.; Ekundayo, O.; Paul, C.; Koenig, W. A.; Eshilokun, A. O.; Yadua, P.; J.
Essent. Oil Res. 2004, 16, 582; Rana V. S.; Prasad, D.; Blazquez, M. A.; J. Essent. Oil Res. 2005, 17, 198; Randrianalijaona, JA.; Ramanoelina, P. A. R.; Rasoarahona, J. R. E; Gaydou, E. M.; Anal. Chim. Acta 2006, 545, 46; Randrianalijaona, J-A; Ramanoelina, P. A. R.; Rasoarahona, J. R. E; Gaydou, E. M.; J. Essent. Oil Res. 2006, 18, 405.

6. Saxena, V. K.; Sharma, R. N.; Fitoterapia 1999, 70, 67; Deena, M. J.; Thoppil, J. E.; Fitoterapia 2000, 71, 453.

7. Bouda, H.; Tapondjou, L. A.; Fontem, D. A.; Gumedzoe, M. Y. D.; J. Stored Prod. Res. 2001, 37, 103.

8. Amaral, C. L. F.; Silva, A. B.; Biotecnologia Ciência e Desenvolvimento 2003, 30, 55 .

9. Collin, H. A.; Plant Growth Regul. 2001, 34, 119.

10. Sakamura, F.; Ogihara, K.; Suga, T.; Taniguchi, K.; Ryuso, T.; Phytochemistry 1986, 25, 1333; El-Keltawi, N. E.; Croteau, R.; Phytochemistry 1987, 26, 675; El-Keltawi, N. E.; Croteau, R.; Phytochemistry 1987, 26, 891; Sudriá, C.; Pinol, M. T.; Palazón, J.; Cusidó, R. M.; Vila, R.; Morales, C.; Bonfill, M.; Cañigueral, S.; Plant Cell Tissue Organ Cult. 1999, 58, 177; Sudriá, C.; Palazón, J.; Cusidó, R.; Bonfill, M.; Piñol, M. T.; Morales, C.; Biol. Plant. 2001, 44, 1; Phatak, S. V.; Heble, M. R.; Fitoterapia 2002, 73, 32; Arikat, N. A.; Jawad, F. M.; Karam, N. S.; Shibli, R. A.; Sci. Hortic. 2004, 100, 193; Santos-Gomes, P. C.; Fernandes-Ferreira, M.; J. Agric. Food Chem. 2003, 51, 2260; Silva, S.; Sato, A.; Lage, C. L. S.; San Gil, R. A. S.; Azevedo, D. A.; Esquibel, M. A.; J. Braz. Chem. Soc. 2005, 16, 1387.

11. Tavares, E. S.; Lopes, D.; Bizzo, H. R.; Lage, C. L. S.; Leitão, S. G.; J. Essent. Oil Res. 2004, 16, 405.

12. Affonso, V. R.; M. Sc. Dissertation, Universidade Federal do Rio de Janeiro, Brazil, 2005.

13. Murashige, T.; Skoog, F.; Physiol. Plant. 1962, 15, 473.

14. Adams, R. P.; Identification of Essential Oil Components by Gas Cromatography/Mas Spectroscopy, Allured Publishing Corporation: Carol Stream, Illinois, USA, 1995.

15. Rohlof, J.; J. Agric. Food Chem. 1999, 47, 3782; Dudai, N.; Larkov, O.; Ravid, U.; Putievsky, E.; Lewinsohn, E.; Ann. Bot. 2001, 88, 349; Russel, M.; Southwell, J.; Phytochemistry 2002, 59, 709; Mirjalili, M. H.; Salehi, P.; Sonboli, A.; Vala, M. M.; Chem. Nat. Compd. 2006, 42, 19.

Received: April 17, 2007

Web Release Date: December 6, 2007 